\title{
The Influence of Edge Effect on Diversity of Amphibian (Ordo Anura)
}

\author{
Ana Widiana $^{1}$, Astri Yuliawati ${ }^{2}$, Rizal M. Hasby ${ }^{3}$, M. Danil ${ }^{4}$ \\ \{anawidiana@uinsgd.ac.id ${ }^{1}$, astriyuliawati@uinsgd.ac.id ${ }^{2}$, rizal.maulana@fst.uinsgd.ac.id ${ }^{3}$ \} \\ ${ }^{1,3,4}$ Department of Biology Faculty of Science and Technology UIN Sunan Gunung Djati Bandung, \\ ${ }^{2}$ Department of Educational Biology Faculty of Tarbiyah and Teacher Training UIN Sunan Gunung Djati \\ Bandung
}

\begin{abstract}
Ecotone is the transition area between two different communities. This area is usually characterized by higher biodiversity compared to the core area as a result of edge effects. Amphibians are fauna that sensitive to climate change because they have semipermeable skin. Changes the function of land in the area affect ecotones which have an impacts on amphibians. This study aim was to determine the diversity of amphibians in the edge areas as a result of forest fragmentation in the Situ Patengan area. Sampling was done at night by Visual Encounter Survey method at nine plot (H1 : Forest $1 ; \mathrm{H} 2$ : Forest 2; H3 : Forest 3; T : Tea plantation; S : Strawberry plantation; P : Residential areea); E-HT : Forest 1 and Tea plantation Ecoton; E-HS : Forest 2 and Strawberry plantation; E-HP: Forest 3 and Residential area ecoton) with three replication. The result showed that there were five species in forest ecotone with a tea plantation. In forest ecotone with a strawberry plantation was obtained six species, meanwhile in forest ecotone with residential area was obtained one species. The results of the diversity index data analysis showed that the highest diversity index of amphibian was forest and tea plantation ecotone (1.376) and it included as the medium category. Meanwhile, the lowest diversity index of amphibian was on ecotone between forest and residential area (0) and included as the low category. As a result, edge effect had both positive and negative impact on amphibian diversity.
\end{abstract}

Keywords: Amphibian, Diversity, Ecotone, Edge Effect

\section{Introduction}

Amphibians are one of the ecosystem components, play crucial role for the continuity of ecological processes. Iskandar stated that they are the primary predators of insects or other invertebrate animals and can be used as a good bio indicator to assess forest conditions because amphibians are very sensitive to climate change [1]

The existence of amphibian populations can be influenced by several factors, namely overfishing, loss of forests and wetlands, pollution, diseases, introduced species, and physical defects [2]. The most influential factor that effected amphibians populations are habitat lost due to the land conversion of forest and wetland. This conversion lead the formation of edge habitats.

Edge habitats are formed if a forest area is changed for non-forestry functions, such as roads or residential areas. One consequence of the changing function of the area is effected 
environmental conditions. This condition can cause edge effects. The term of edge effect was first used by Leopold to describe the trend of increasing species diversity in non-intact landscapes. With many recent discoveries that reveal various forms of response of plants and animals and other organisms to environmental conditions in edge habitats, the concept of edge effects has developed. The response of plants and animals not only shows a tendency to increase species diversity but also shows a decline or without change [3].

Species diversity is one of variables can be used for conservation management. Changes in species richness is an indikator for predicting and evaluating the community's response to management activities. This study aimed to predict the edge effects on the diversity of Order Anura amphibians in fragmented areas

\section{Materials and Methods}

The research conducted at Situ Pantengan Area, Ciwidey, West Java. This area located in altitude of 1600-1700m height above sea level.. We observed 9 spots in that area namely: $\mathrm{H} 1$ (forest 1), H2 (forest 2), H3 (forest 3), T (tea plantation), S (strawberry plantation), $\mathrm{P}$ (residential area), H1-T (forest 1 and tea plantation ecoton), H2-S (forest 2 and strawberry plantation) and H3-P (forest 3 and residential area ecoton). The community of forest does not connected each other.

The plot was made on the border of two different communities by tracing the $400 \mathrm{~m}$ long track, 5 meters wide to the left and right side with three replications (for ecoton area) and 50 meters from ecoton border (for each communities). Sample of Annura collected at night at 6:00 a.m. to 10:00 p.m. The samples identified by book of Field Guide (Inger and Stuebing, 1997).

\subsection{Observation}

This study used the VES method (visual encounter survey) (Kusrini, 2013). Field data includes species name, number of individuals, body length SVL (snout-vent length), time and behavior when found. The habitat component data observed based on the checklist of Heyer et al. (1994) includes the date and time of data collection, location, substrate / environment where it was found, vegetation type and altitude, distance of the water area to the observation area, air temperature, water temperature, air humidity and water $\mathrm{pH}$.

\subsection{Data Analysis}

Species Diversity Index

Shannon-Wiener Index was used to determine species diversity. This index value was used to compare the diversity of amphibians on each observation area.

$$
\mathrm{H}^{\prime}=-\sum \frac{n_{i}}{N} \times \operatorname{In} \frac{n_{i}}{N}
$$

$H^{\prime} \quad=$ Shannon Weiner diversity index

$n_{i} \quad=$ Individual number of species $-\mathrm{i}$

$N \quad=$ Total individual number 


\section{Evenness} location.

Evenness was calculated to determine the degree of evenness of the species at the study

$$
E=\frac{H^{\prime}}{\operatorname{InS}}
$$

$E \quad=$ Species evenness index

$H^{\prime} \quad=$ Shannon Weiner diversity index

$S \quad=$ Total species found

Species Abundance

Abundance was used to determine the density of individuals in an ecosystem.

$$
D_{i}=\frac{N_{i}}{N} \times 100 \%
$$

$D_{i} \quad=$ Relatives Abundance (\%)

$N_{i} \quad=$ Individual number each species

$N \quad=$ Total individual number

\section{Result and Discussion}

Nine amphibians species found in the study area consisted of five families, namely Bufonidae, Dicroglossidae, Megophryidae, Ranidae, and Rhacophoridae. All those recorded family are belong to Order of Anura. The Order of Gymnophiona was not found during the observation. All species found are identified based on the morphological characteristics.

The five families the anura order were found spread in several types of communities and also found in ecotonous areas which restricted one community to another, as shown in table 1 .

\begin{tabular}{|c|c|c|c|c|c|c|c|c|c|c|}
\hline \multirow{2}{*}{ Family } & \multirow{2}{*}{ Species } & \multicolumn{9}{|c|}{ Communities type } \\
\hline & & H1 & H1-T & $\mathrm{T}$ & $\mathrm{H} 2$ & H2-S & $\mathrm{S}$ & H3 & H3-P & $\mathrm{P}$ \\
\hline Bufonidae & Duttaphrynus melanostictus & & $\sqrt{ }$ & & & & $\sqrt{ }$ & $\sqrt{ }$ & $\sqrt{ }$ & $\sqrt{ }$ \\
\hline \multirow[t]{2}{*}{ Dicroglossidae } & Limnonectes kuhlii & $\sqrt{ }$ & & & & & & & & \\
\hline & Limnonectes microdiscus & & & & & $\sqrt{ }$ & & & & \\
\hline Megophryidae & Leptobrachium hasseltii & $\sqrt{ }$ & $\sqrt{ }$ & $\sqrt{ }$ & $\sqrt{ }$ & $\sqrt{ }$ & & $\sqrt{ }$ & & \\
\hline
\end{tabular}

Table 1. Amphibian species in type of communities 


\begin{tabular}{lllllll}
\hline & Megophrys montana & $\sqrt{ }$ & $\sqrt{ }$ & $\sqrt{ }$ & & \\
Ranidae & Hylarana chalconota & & $\sqrt{ }$ & $\sqrt{ }$ & $\sqrt{ }$ & \\
& Hylarana nicobariensis & & $\sqrt{ }$ & $\sqrt{ }$ & \\
& Odorrana hosii & $\sqrt{ }$ & & & & \\
Rhacophoridae & Rhacophorus margaritifer & & & $\sqrt{ }$ & $\sqrt{ } \sqrt{ }$ \\
\hline
\end{tabular}

The data in table 1 shows differences in the number of species found in each observation area, in the ecotone area between forests 1 and tea plantation and ecotones between forests with strawberry plantation showing the highest number of species compared to observation area in their interior habitat. The theory of edge effect states that the number of species and population densities of some species is greater in transitional regions (edges) than in communities that flank them [4]. The edge effects are not entirely detrimental, the presence of edge effects often creates habitat for species that are tolerant of open and closed areas. However, only one species was found in the ecotone between forests and residential area [5] . This is due to the observation location on the ecotone between forest 3 and residential area in the form of cliffs and has a very steep slope and there are disturbances in human activities because there is a lot of garbage. From this result we can conclude that not every ecotone has higher number of amphibian species. Generally herpetofauna, especially amphibians, prefer core areas because they have colder, more humid temperatures which are more conducive to survival especially during dry periods [6] [7], and the habitat degradation would form a transitional area causing a decrease in litter which caused a decline in the population of litter frogs. Whereas Dawson and Hostetler did not find any real differences in composition and species richness in transitional regions and core areas [9]. According to canopy cover, litter cover, understory density, litter depth, and temperature variation will affect the difference in composition and wealth of herpetofauna species between transitional and core regions [10].

The Duttaphrynus melanostictus species was found in five observation locations, namely in the ecotone between forests 1 with tea plantation, strawberry plantation, forests 3 , ecotone between forests3-recidential area and at residential area. This species is often found on terrestrial lines or on land floors which are sometimes far from water as can be found in residential areas. This species is the most common type found in various places including large villages and towns, processed land, open spaces, gardens, ditches and roadsides and is usually on dry land, on grass and above litter [2].

The family of Dicroglossidae Limnonectes kuhlii and Limnonectes microdiscus was found in forest and ecotone between forest and strawberry plantation. Generally Dicroglosidae family found at the riverbank location in the observation area, in line statement that those species habitats is around the river and will not be far from the flow of water [2].

The Leptobrachium hasseltii at the time of observation was found in six observation locations, namely at forest location 1, ecotone between forest and tea plantation, tea plantation, forest 2 , ecotone between forest and strawberry plantation and at forest 3 , at all these locations there were litter, litter is the suitable habitat of Leptobrachium hasseltii species. Which states that Leptobrachium hasseltii only found in locations where the soil is covered with litter such as forests and tea gardens, because this species tends to hide in the litter to protect it from predators [1]. 
On this observation, the Megophrys Montana was found in three locations namely forest 1 , the ecotone between the forest and the tea plantation and the ecotone location between the forest with strawberry plantation, most of Megophrys montana are often found in terrestrial habitats where there are lots of litter or covered. Megophrys montana is a litter frog that inhabits the terrestrial habitat and its entire activities are carried out on land such as living, sleeping, moving and foraging [11].

Hylarana chalconata was found in four locations, namely the ecotone between the forest and the tea plantation, the ecotone between the forest and the strawberry plantation, the strawberry plantation and the residential area. Most Hylarana chalconata are found in areas near water or not far away from water. In some observation plots was found streams of water or puddles which are the habitat of this species. This species has a full membrane which indicates that the species prefers aquatic habitat. Hylarana chalconota frog species are semi arboreal and include non-forest species that like degraded habitats due to human activities, such as fish ponds, non-permanent ponds and irrigation ditches around human settlements [12].

Hylarana nicobariensis was found in two observation locations, namely at the ecotone between the forest and the tea plantation and at the location of the ecoton between the forest and the strawberry plantation. Hylarana nicobariensis usually found on forest borders in disturbed areas, around slow or stagnant water [2].

Species Rhacophorus margaritifer was found in three observation locations namely the ecotone location between the forest with strawberry plantation, strawberry plantation and at forest 3 , this type of frog is an arboreal frog because of its activity on trees. This species was found in the location that have water flow or puddles with tree around it. At the time they were found in the stems and leaves of the tree around the river or pond, and Rhacophorus margaritifer spends much of its activities in plants and is not far from water sources [13].

Each type has a different ecological distribution, the ecological distribution is described by the position when the amphibians were found. The position is divided into horizontal and vertical [14]. The horizontal position describes the reference to water sources, accompanied by shade. The vertical position in terrestrial habitats is described as a reference to the subsurface position on open ground, shaded and underground or water. As can be seen in the table below.

Table 2 Ecological Distribution of Each Species

\begin{tabular}{lcc}
\hline \multicolumn{1}{c}{ Species } & Vertical & Horition \\
\cline { 2 - 3 } & On the ground & Far from water \\
Limttaphrynus melanostictus & On the ground & Near from water \\
Limnonectes microdiscus & On the ground & Near from water \\
Leptobrachium hasseltii & On the ground and litter & Far from water and shaded \\
Megophrys montana & On the ground and litter & Far from water and shaded
\end{tabular}


Hylarana chalconota

Hylarana nicobariensis

Odorrana hosii

Rhacophorus margaritifer
On the ground and leaves

On the ground

On the ground, leaves and stems

On the leaves
Near from water

Near from water

Near from water

Near from water

This presence shows that there are several types of amphibians that have climate-specific habitat in the surrounding area, or known as the term microhabitat. Amphibians like this are referred to as specialist amphibian types. In addition there are also generalist amphibians (living in common habitats, even in polluted habitat conditions)

\subsection{Species abundance}

138 total individuals from nine different species of anura was found on this observation. The results of the species abundance calculation showed that, Hylarana chalconota had the highest number of individuals (31\%) after that Duttaphrynus melanostictus (23\%) and Leptobrachium hasseltii (19\%), while the species with the least number of individuals, were Limnonectes kuhlii and Limnonectes microdiscus, and were found only one individual $(0.70 \%)$. These results can be seen in the following Figureure.

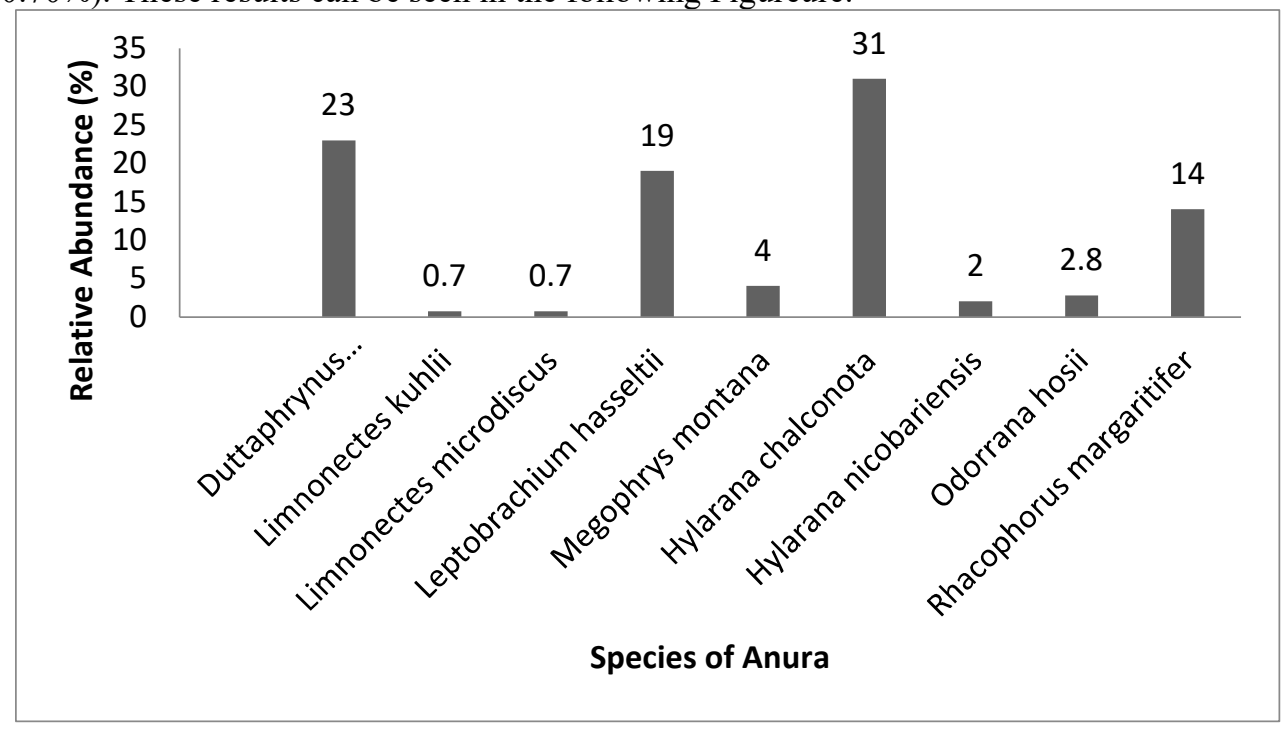

Fig.1 Species Abundance

The high individual number of Hylarana chalconota in river habitats is due to their breeding season almost throughout the year [15]. The air temperature has a significant effect on the development and growth of amphibians, and often regulates the cycle of behavior and reproduction. Amphibians are poikilothermic species that cannot regulate their own body 
temperature so that their body temperature is very dependent on their environmental conditions. The air temperature at the study location ranged from 15.2 to $18.5^{\circ} \mathrm{C}$. Air humidity obtained ranges from $59 \%$ to $85 \%$ [16]. The physical characteristics of the research location shows that it is suitable for amphibian life in general, factors that affect frogs are $\mathrm{pH}$ of river water, temperature and humidity and forest structure. In addition, the availability of food sources is positively correlated with the species richness of frogs [17].

\subsection{Species Evenness}

On the nine observation area, the highest species evenness is residential area $(\mathrm{E}=$ 0.9154 ) and the lowest is tea plantation, forest 2 and the ecotone between forests and residential area $(E=0)$, this can be seen on Figureure 2. The value of $E$ is said to be evenly distributed if it approaches 1 and is said to be uneven if it approaches 0 .

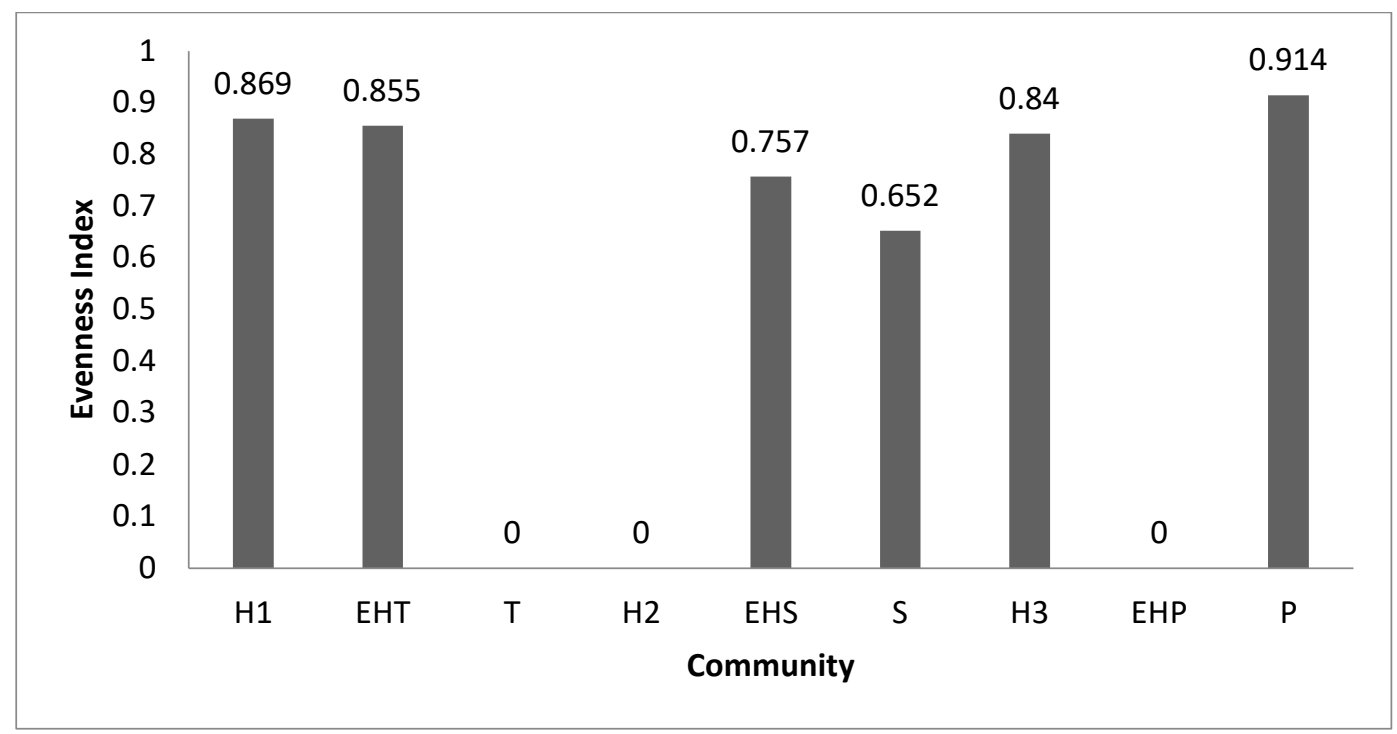

Fig.2. Evenness Index

From Figureure 2 it can be seen that evenness in residential areas is higher than other regions, because in that location the number of individuals per species is relatively the same, whereas in the location of tea plantations and forests 2 there are species that have a more dominant number of individuals, Leptobrachium hasseltii. Based on the observations, this species easily found in these locations because there are many litter. Litter which is indeed a place favoured by this species, this is corroborated by the statement which states that Leptobrachium hasseltii found only in locations where the soil is covered with litter such as forests and tea plantation, because this species tends to hide in the litter to protect it from predators [1]. Evenness can be used as an indicator of the species that dominates a community [18]. So that the dominance of a species will be high if evenness is low, and vice versa. 


\subsection{Species Diversity}

Amphibian diversity values differed at each observation location. The value of diversity at the observation locations ranged $(0-1,376)$, the value is relatively low. A high level of diversity is indicated by the Shannon-Wiener diversity index value classified as medium with a value of $1.5-3.5$ and classified as low if the value is below 1.5 [19].

The calculation of the Shannon-Wiener diversity index shows that the ecotone between forests and tea plantation $\left(\mathrm{H}^{\prime}=1,376\right)$ has the highest diversity after ecotone between forests with strawberry plantation $\left(\mathrm{H}^{\prime}=1,356\right)$ and Forest $1\left(\mathrm{H}^{\prime}=1,205\right)$. Tea plantation, Forest 2 and the ecotone between forests and residential area have the lowest diversity $\left(\mathrm{H}^{\prime}=0\right)$.

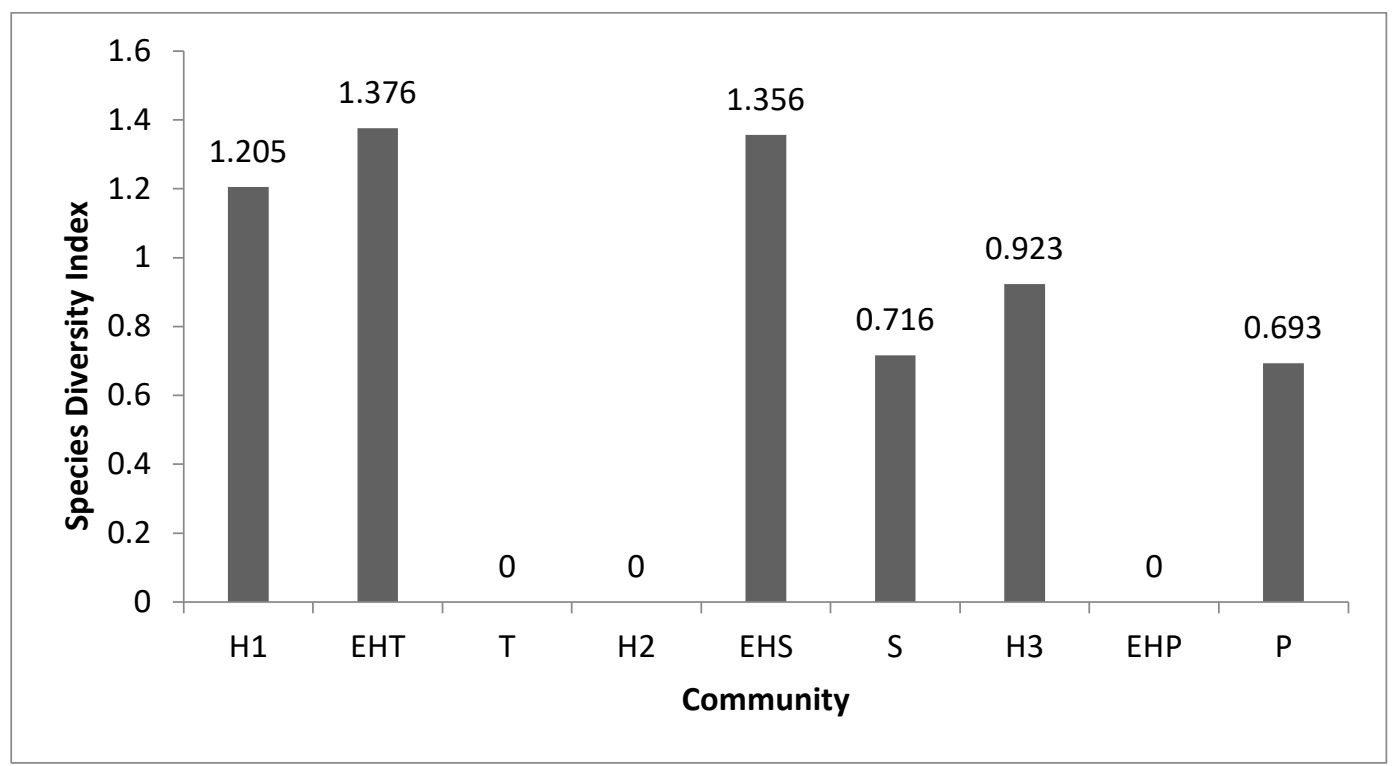

Fig.3 Species Diversity Index

At the ecotone location between the forest and the tea plantation and the ecotone between the forest and the strawberry plantation has the highest diversity value, this is presumably because the location of the structure from the ecotonous area which is a transition from two different communities is quite significant so that species found in both communities can be found or also because the ecotone can be a habitat for certain species. The lowest diversity value is found in the location of tea plantations, forest 2 and ecotone between forests and residential area, only one species was found in this location, it cause by tea plantations and forests 2 are quite far from aquatic habitat so the species found are inhabiting species in terrestrial habitat.

The value of species diversity in a community is not only influenced by the number of species but also the abundance of each species in a community [4]. There are 6 factors that influence species diversity, namely time, space heterogeneity, competition, stable environment, predation and productivity [20]. Whereas compatibility with temperature and humidity, canopy closure and soil formation are factors that influence diversity [21]. 


\section{Conclusion}

The ecotone between the forest and the tea plantation has the highest diversity of Anura $\left(H^{\prime}=1,376\right)$, followed by the ecotone between the forest and the strawberry plantation $\left(\mathrm{H}^{\prime}=1,356\right)$ and Forest $1\left(\mathrm{H}^{\prime}=1,205\right)$. Tea plantation, Forest 2 and the ecotone between forests and residential area have the lowest diversity $\left(\mathrm{H}^{\prime}=0\right)$. Edge effects were affect to diversity of Anura in certain regions.

\section{Refferences}

[1] D. T. Iskandar, "Amphibians of Java and Bali. Field Guide Series. Puslitbang-LIPI, Bogor," 1998.

[2] M. D. Kusrini, "Pictured Guide of West Java Amphibians Identification. Faculty of Forestry IPB, Bogor," 2013.

[3] T. Reis, L., Fletcher, R., Battin, J, and Sisk, "Ecological Responses to Habitat Edges Mechanisms, Models, and Variability Explained. Annual Review. Ecology, Evolution, and Systematics.Vol 35, pp. 491-522," 2004.

[4] E. P. Odum, "Koleksi Buku 1993," Basic Ecol., no. Yogyakarta : Gadjah Mada University Press, p. 1993, 1993.

[5] W. D. Lidicker, W.Z. Jr and Kooenig, "Responses of Terestrial Vertebrates to Habitat Edges and Corridor. Island Press, Washington DC (US)," 1996.

[6] M. A. Schlaepfer and T. A. Gavin, "Edge effects on lizards and frogs in tropical forest fragments," Conserv. Biol., vol. 15, no. 4, pp. 1079-1090, 2001, doi: 10.1046/j.15231739.2001.0150041079.x.

[7] J. . Lethinen, R.M., Ramanamanjato, "and Edge Effects and Ecxtinction Proneness in a Herpetofauna from Madagascar. Biodevirsity Conservation. Vol. 12, pp. 1357-1370."

[8] M. O. Hillers, A., Veith, M, and R. Odel, "Effects of Forest Fragmentation and Habitat Degradation on West African Leaf. Litter Frogs. Conservation Biology. Vol 22 (3), pp. 762$772, " 2008$.

[9] M. E. Dawson, D.E and Hostetler, "Herpeto Faunal Use of Edge and Interor Habitats in Urban Forest Remnants. Urban Habitats. Pp.1541-7115," 2008.

[10] J. N. Urbina-Cardona, M. Olivares-Pérez, and V. H. Reynoso, "Herpetofauna diversity and microenvironment correlates across a pasture-edge-interior ecotone in tropical rainforest fragments in the Los Tuxtlas Biosphere Reserve of Veracruz, Mexico," Biol. Conserv., vol. 132, no. 1, pp. 61-75, 2006, doi: 10.1016/j.biocon.2006.03.014.

[11] I. D. Susanto, "Final Report Conservation Intern in Alas Purwo National Park, Banyuwangi," 2011.

[12] H. Kurniati, "THE REPTILES SPECIES IN GUNUNG HALIMUN NATIONAL PARK, WEST JAVA, INDONESIA*[Reptilia di Taman Nasional Gunung Halimun, Jawa Barat, Indonesia]," Ber. Biol., vol. 7, no. 1, pp. 73-79, 2004, doi: 10.14203/beritabiologi.v7i1\&2.1238.

[13] N. Mulia, "Daily Locomotion Patern and Utilization of Microhabitat of Javan Tree Frogs (Rachoporus Margaritifer) in Gunung Gede Pangrango National Park, West Java. [Thesis]. Department of Conservation Forest Resources. Faculty of Forestry. IPB, Bogor," 2010.

[14] and N. S. F. Heyer, W.R., Doonelly, M.A., McDiamid, R.W., Hayek, A.A.C, "Measuring and Monitoring Biological Diversity: Standard Methods for Amphibians. Washington Smithsonian Institution Press," 1994.

[15] R. B. Inger, R.F and Stuebing, "A Field Guide to The Frogs of Borneo Sabah. Natural History," 1997.

[16] S. Yuliana, "The Diversity of Amphibians (Ordo Anura) IPB Darmaga Campus, Bogor. 
Department of Conservation Forest Resources. Faculty of Forestry. IPB, Bogor," 2000.

[17] E. Meijaard, "Life after Logging: Reconciling Wildlife Conservation and Production Forestry in Indonesia Borneo. CIFOR and UNESCO, Bogor," 2005.

[18] Y. Santosa, "1995. Concept of Diversity Measurement in Tropical Forest. Department of Conservation Forest Resources. Faculty of Forestry. IPB, Bogor," 1995.

[19] A. E. Magurran, "Ecological Diversity and Its Measurement. Princeton University Press, New Jersey," 1998.

[20] C. J. Krebs, "Ecological Methodology. Harper and Row Publisher, New York," 1978. 